\title{
Sistem Gerak Robot Mainland Surveillance menggunakan Mecanum Wheel sebagai Militer Robot
}

\author{
Fahmizal $^{1}$, Muhammad Arrofiq ${ }^{2}$, Afrizal Mayub ${ }^{3}$
}

\begin{abstract}
Robotics in human life is very important. It is also in the military sector. Modern countries intensively show of force in high technology robot developed. Indonesia has a special army force with a high military skill called Kopasus. Kopasus is a special squad in the mainland. Other countries also include robots as additional equipment to personnel. This military robot would help personnel performing surveillance. In this research, the prototype of surveillance mainland robot has been developed. The prototype could be used by military personnel in surveillance. In order to realize the aim, this paper conducts designing of robot movement mechanism as the main point of view. By using mecanum wheel platform, the surveillance mainland robot is expected to have navigation capability in all directions. The result of this research is a movement of the robot that can move all directions with reference to the east direction is angle $0^{\circ}$, north $\left(90^{\circ}\right)$, west $\left(180^{\circ}\right)$ south $\left(270^{\circ}\right)$. Command directions robots using wireless control manuals integrated with Android smartphones.
\end{abstract}

Intisari- Robotika dalam aspek kehidupan manusia dewasa ini sangatlah penting. Tidak terkecuali pada bidang milter. Saat ini banyak negara berlomba-lomba menunjukkan kemuktahiran robot ciptaannya dalam bidang militer. Indonesia merupakan negara dengan prajurit tempur yang cukup disegani di tingkat Asia, sebut saja Kopasus (Komando Pasukan Khusus). Satuan prajurit Tentara Nasional Indonesia (TNI) ini sangat handal di dalam pertahanan darat Indonesia. Namun hal ini tidak cukup, saat ini banyak negara-negara melibatkan robot sebagai sarana bantu para prajuritnya. Hal ini lah yang mendorong penulis untuk ikut mengambil peran dalam membantu para prajurit Indonesia nantinya dalam hal surveillance atau pengamatan dengan bantuan sebuah robot. Penulis merancang dan mebuat sebuah prototype atau purwarupa robot mainland surveillance yang akan digunakan pada prajurit tentara darat. Tahap awal perancangan mekanisme gerak robot merupakan menjadi titik konsern Penulis. Dengan menggunakan roda platform mecanum wheel, robot diharapkan memiliki navigasi yang memungkinkan dapat bergerak kesegalah arah. Hasil pengujian penelitian ini dicapai sebuah pergerakan robot yang dapat bergerak kesegala arah dengan referensi arah timur sebagai arah sudut $0^{\circ}$, utara $\left(90^{\circ}\right)$, barat $\left(180^{\circ}\right)$ selatan $\left(270^{\circ}\right)$. Pemberian perintah arah robot menggunakan kendali manual wireless yang terinterasi dengan smartphones Android.

Kata Kunci- Mecanum wheel, mainland surveillance robot, inverse kinematika, militer robot.

1,2 Dosen, Departemen Teknik Elektro dan Informatika, Sekolah Vokasi, Universitas Gadjah Mada, Sekip Unit III, Gd. Herman Yohanes, Yogyakarta 55281, Telp: (0274) 561111; Fax.: (0274) 542908,e-mail:fahmizal@ugm.ac.id; rofiq@ugm.ac.id

${ }^{3}$ Dosen, Pascasarjana S2 Pendidikan IPA FKIP, Universitas Bengkulu, Jl. WR Supratman, Bengkulu 38371, Telp: +62 736 21186; Fax.: +62 736 21186, e-mail: afrizalmayub@unib.ac.id

Fahmizal: Sistem Gerak Robot Mainland Surveillance ...

\section{PENDAHULUAN}

Dewasa ini perkembangan teknologi semakin berkembang pesat, salah satunya perkembangan teknologi robot. Berbondong-bondong negara yang ada di dunia ini melakukan banyak riset dalam hal perkembangan teknologi robot. Seolah tak mau kalah negara-negara maju seperti Amerika Serika, Jepang, Korea Selatan dan China terus melakukan inovasiinovasi terbaru dalam hal perancangan dan penggunaan teknologi tinggi dalam robot-robot yang mereka ciptakan. Di Indonesia sendiri perkembangan teknologi pada bebrerapa tahun terakhir ini mulai mengalami perkembangan jika dibandingkan beberapa dekade lalu.

Salah satu faktor lambatnya perkembangan teknologi robot di Indonesia adalah minat masyarakat Indonesia yang masih sangat minim dengan teknologi robot, ditambah lagi dengan sangat jarang dijumpai perguruan tinggi yang memiliki perkuliahan yang khusus tentang robot. Namun sejak mulai maraknya lomba teknologi robot yang diadakan oleh Direktorat pendidikan Tinggi (DIKTI), kini hampir di setiap perguruan tinggi di Indonesia memiliki tim robot yang siap bertanding dalam berbagai acara perlombaan robot baik di sakala nasional maupun internasional. Hal ini juga mendorong penulis untuk ikut andil dalam hal mengembangkan teknologi robot di Indonesia.

Pada penelitian ini, penulis mengambil topik dalam mengembangkan suatu robot mainland surveillance yang dapat diperbantukan sebagai salah satu bagian personel dalam militer darat tepatnya sebagai robot militer. Negara Indonesia memiliki satuan prajurit Tentara Nasional Indonesia (TNI) yang sangat handal di dalam pertahanan darat Indonesia, sebut saja satuan tersebut adalah Kopasus. Dengan adanya sebuah robot militer yang mampu bekerja sama dengan Kopasus maka dapat membantu memaksimalkan kerja dari Kopasus tersebut dalam hal surveillance (pengamatan).

Amerika Serikat sebagai negara adi kuasa melakukan perkembangan teknologi robot dalam bidang militer, kesehatan dan antariksa. Berbagai upaya mereka lakukan dengan dana yang tak terbatas demi menciptakan robot-robot andalan mereka, salah satunya adalah robot tank seperti pada Gambar 1(a). Selain itu, kementerian pertahanan Rusia menegaskan konsep pengembangan sistem teknologi robotik akan mengarah ke bidang militer seperti pada Gambar 1(b). Berdasarkan informasi dari kementerian pertahanan Rusia, robot akan masuk dalam perbendaharaan senjata pasukan Rusia pada tahun 2017-2018, dan menjelang tahun 2025 robot akan mengisi 30 persen dari keseluruhan teknologi senjata angkatan bersenjata Rusia.

Berlatar belakang kajian pustaka, mendorong penulis untuk mencoba mendesain suatu robot mainland surveillance, namun tidak menggunakan roda tank melainkan roda mecanum. Roda mecanum atau mecanum wheel adalah salah

$$
\text { p-ISSN:1693 - 2951; e-ISSN: 2503-2372 }
$$


satu desain roda yang dapat digunakan sebagai platform kesegala arah. Mecanum wheel didesain dan diciptakan di Swedia pada tahun 1975 oleh Bengt Ilon. Roda ini biasanya digunakan dalam aplikasi robot yang membutuhkan tingkat tinggi dalam hal bermanuver [1], seperti yang dibutuhkan oleh NASA atau eksplorasi lingkungan yang berbahaya (Lippitt \& Jones 1998) dan Airtrax [2] untuk kendaraan truk forklift pada yang dijelaskan pada Gambar 2.

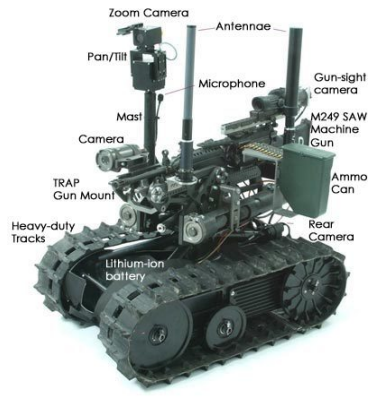

(a)

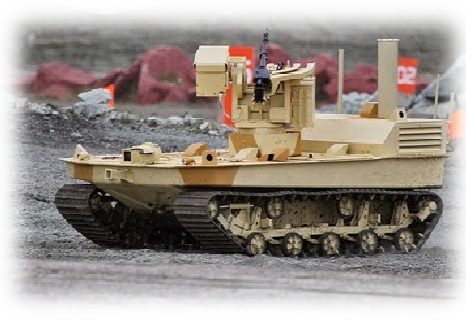

(b)
Gambar 1. (a) Amerika robotik tank dan (b) Rusia robotik tank.

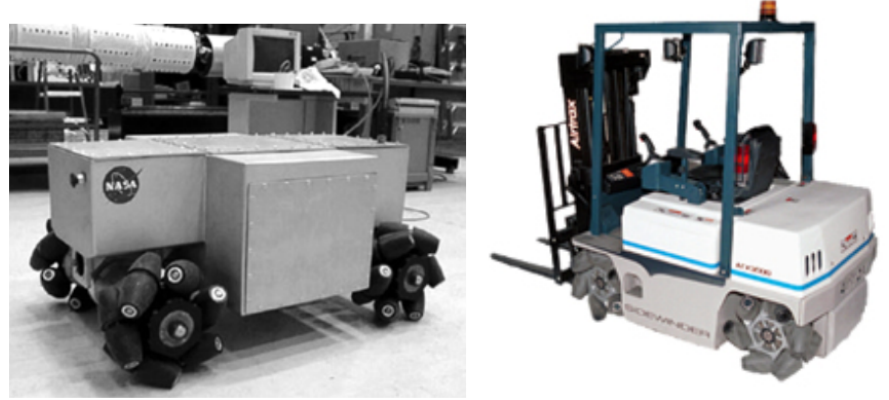

Gambar 2. NASA OmniBot (kiri) dan Airtrax Sidewinder lift truck (kanan) (Airtrax 2006).

\section{MATERI DAN METODOLOGI}

\section{A. Roda Mecanum}

Mecanum wheel memiliki keunikan tersendiri, dengan desain quad position seperti Gambar 3 dengan rodanya yang berjumlah 4 buah, mecanum wheel memiliki kelebihan yang dapat bergerak kesegala arah. Berbeda dengan robot omni wheel, dimana omni wheel pemasangan rodannya harus simetris dan saling berhadapan, sementara pada mecanum wheel pemasangan persis seperti mobil biasa [3]. Bentuk roda luar yang hampir mirip bentuk diagonal menyebabkan pembentukan arah pergerakan robot, tergantung bagian roda mana yang berputar dan menggunakan prinsip resultan gaya [4] $-[5]$.
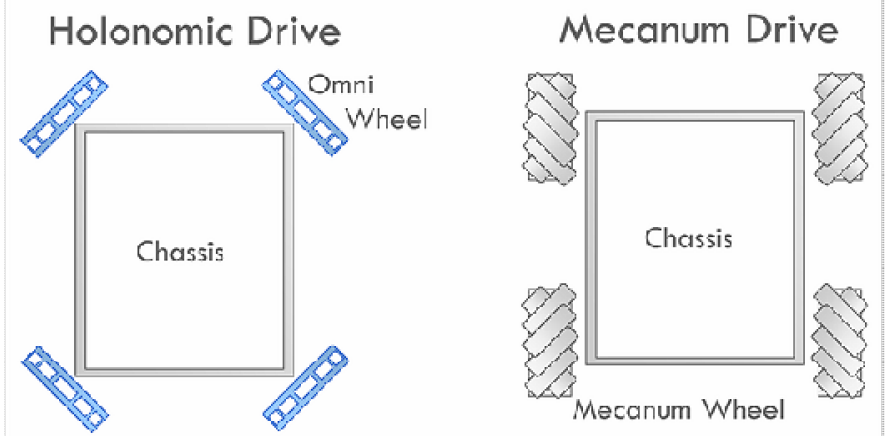

Gambar 3. Omni wheel (kiri) dan Mecanum wheel (kanan)

Ilustrasi pengendalian arah robot dengan menggunakan mecanum wheel dapat digambarkan pada Gambar 4. Pada penelitian ini penulis mencoba mengembangkan sebuah robot mainland surveillance dengan menggunakan roda mecanum. Alasan kuat penulis ialah dengan konfigurasi menggunakan tipe roda mecanum akan membuat pergerakan dan arah maneuver robot mainland surveillance menjadi lebih luas atau bisa dikatakan dapat kesegala penjuru arah.

\section{B. Inverse Kinematic pada Mecanum Wheel Platform}

Penelitian mainland surveillance robot ini akan dimulai dari penyelesaian penuruman rumus invers kinematika yang digunakan sebagai dasar perhitungan arah gerak robot. Dari hasil perhitungan invers kinematik ini maka arah pergerakan robot dapat bergerak menuju kesegala arah. Dangan mengacu dari persamaan vektor yang digambar pada Gambar 5 .

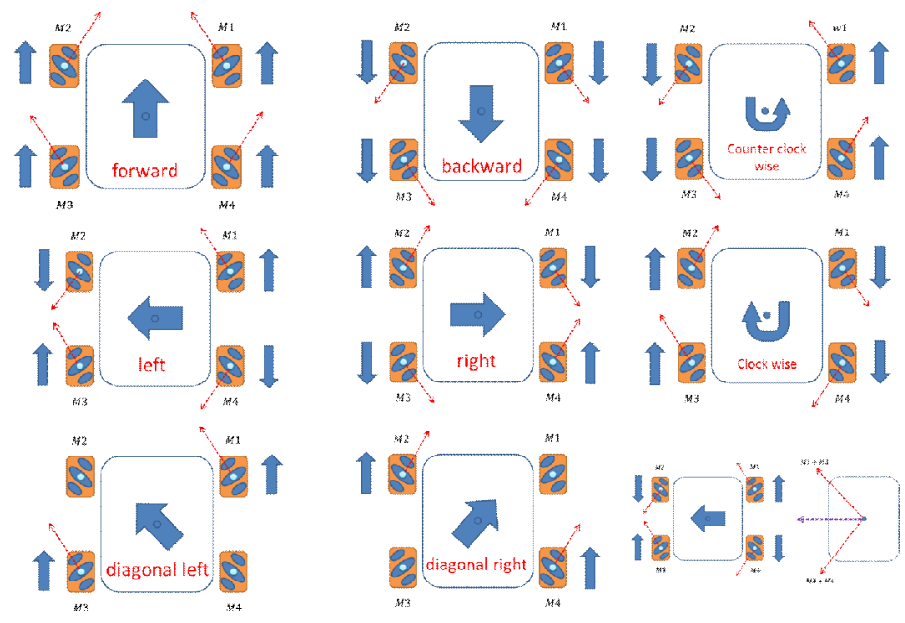

Gambar 4. Ragam teknik arah putar roda sebagai penentu arah pada mecanum wheel. 


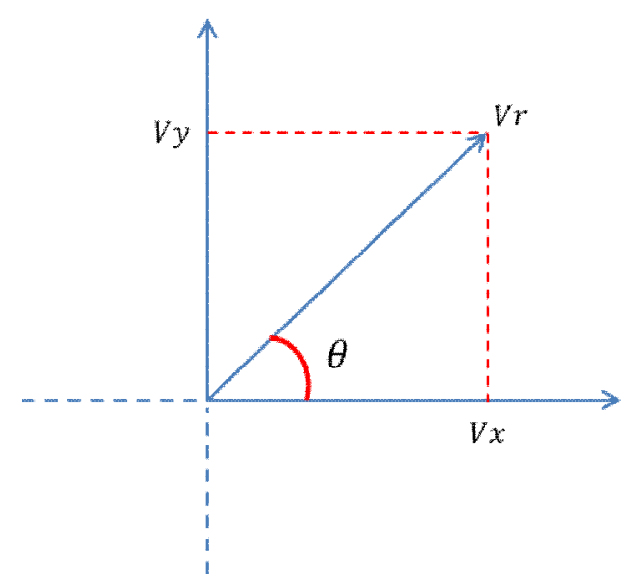

Gambar 5. Arah vektor kecepatan pada mecanum wheel.

$$
V_{r}=\sqrt{V_{x}^{2}+V_{y}^{2}}
$$

Dari persamaan dasar (1) tersebut dijadikan sebagai referensi dan acuan dalam hal penurunan rumus invers kinematika mecanum wheel yang akan diterapkan pada keluaran kecepatan masing - masing pada mecanum wheel yang tergambarkan pada Gambar 6.

Jika diketahui resultan kecepatan robot $\left(\mathrm{V}_{\mathrm{r}}\right)$ dan arah robot $(\theta)$, maka dapat ditentukan arah kecepatan sumbu-y $\left(\mathrm{V}_{\mathrm{y}}\right)$ dan arah kecepatan sumbu- $\mathrm{x}\left(\mathrm{V}_{\mathrm{x}}\right)$ yang mana nantinya akan digunakan sebagai inverse solution pada mecanum wheel. Adapun proses langkah penurunan rumusnya ialah sebagai berikut:

$$
\begin{gathered}
\theta=\tan ^{-1} \frac{V_{y}}{V_{x}} \\
V_{r}^{2}=V_{x}^{2}+V_{y}^{2} \\
V_{y}^{2}=V_{r}^{2}-V_{x}^{2} \\
V_{y}=\sqrt{V_{r}^{2}-V_{x}^{2}}
\end{gathered}
$$

Dengan mensubtitusi persamanaan 5 ke 2, maka diperoleh:

Fahmizal: Sistem Gerak Robot Mainland Surveillance ...

$$
\begin{aligned}
& \theta=\tan ^{-1} \frac{V_{y}}{V_{x}} \\
& \theta=\tan ^{-1}\left(\frac{\left.V_{y}^{2}\right)^{\frac{1}{2}}}{V_{x}^{2}}\right)^{-1}\left(\frac{V_{r}^{2}-V_{x}^{2}}{V_{x}^{2}}\right)^{\frac{1}{2}} \\
& \theta=\tan ^{2} \\
& (\tan \theta)^{2}=\frac{V_{r}^{2}-V_{x}^{2}}{V_{x}^{2}} \\
& (\tan \theta)^{2}=\frac{V_{r}^{2}}{V_{x}^{2}}-1 \\
& V_{x}^{2}=\frac{V_{r}^{2}}{(\tan \theta)^{2}+1} \\
& V_{x}=\sqrt{\frac{V_{r}^{2}}{(\tan \theta)^{2}+1}} \\
& V_{x}^{2} \\
& (\tan
\end{aligned}
$$

Dari penyelesain penurunan rumus (5) dan (6), maka dapat diperoleh nilai $V_{y}$ dan $V_{x}$ yang nantinya akan digunakan pada invers kinematic solution on mecanum wheel robot pada persamaan .

$$
\begin{aligned}
& {\left[\begin{array}{l}
\omega_{1} \\
\omega_{2} \\
\omega_{3} \\
\omega_{4}
\end{array}\right]=\frac{1}{R}\left[\begin{array}{ccc}
1 & 1 & -\left(l_{1}+1_{2}\right) \\
1 & -1 & \left(1_{1}+l_{2}\right) \\
1 & -1 & -\left(l_{1}+1_{2}\right) \\
1 & 1 & \left(1_{1}+l_{2}\right)
\end{array}\right]\left[\begin{array}{c}
V_{x} \\
V_{y} \\
\omega_{z}
\end{array}\right]} \\
& {\left[\begin{array}{l}
V_{1} \\
V_{2} \\
V_{3} \\
V_{4}
\end{array}\right]=\left[\begin{array}{l}
R \omega_{1} \\
R \omega_{2} \\
R \omega_{3} \\
R \omega_{4}
\end{array}\right]=\left[\begin{array}{ccc}
1 & 1 & -\left(1_{1}+1_{2}\right) \\
1 & -1 & \left(1_{1}+1_{2}\right) \\
1 & -1 & -\left(l_{1}+1_{2}\right) \\
1 & 1 & \left(l_{1}+1_{2}\right)
\end{array}\right]\left[\begin{array}{l}
V_{x} \\
V_{y} \\
\omega_{z}
\end{array}\right]}
\end{aligned}
$$

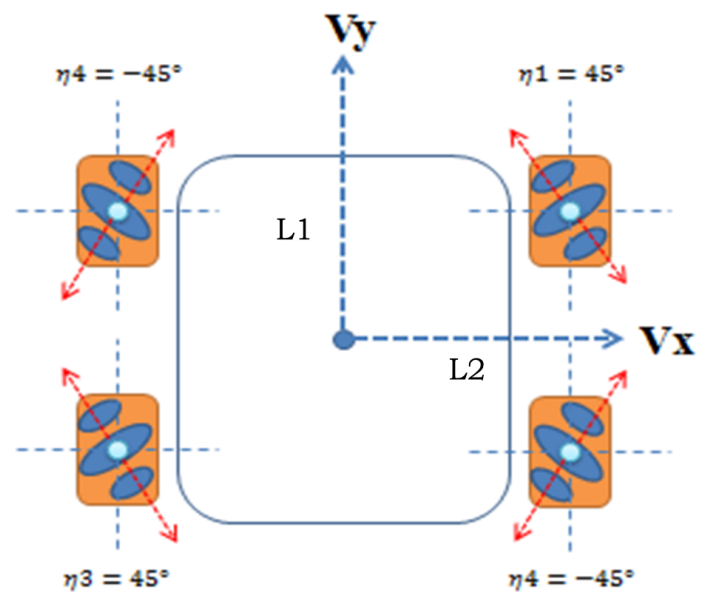

Gambar 6. Posisi mecanum wheel dengan konfigurasi quad position.

C. Persiapan Penelitian

p-ISSN:1693 - 2951; e-ISSN: 2503-2372 
Pada tahapan ini penulis melakukan analisis kebutuhan, penelitian ini membutuh pensinergian multidisiplin ilmu yang terdiri dari bidang ilmu teknik elektro, teknik mesin dan komputer image processig. Adapun deskriptif dari segment disiplin ilmu dijabarkan sebagai berikut [6] - [7]:

a. Elektronika

Diperlukan kemampuan dalam bidang mendesain dan membuat circuit controller atau embedded system pada robot.

b. Mekanika

Diperlukan kemampuan dalam bidang mendesain dan membuat mekanikal struktur robot yang akan dirancang.

c. Kontrol

Diperlukan kemampuan dan memahami teoritikal dan praktikal untuk mengendalikan masukan yang didapat dari pembacaan sensor robot dan memahami pengolahan sinyal aktuasi pada robot. Lebih jauh memahami teknik navigasi yang dapat di terapakan pada robot seperti pada [8]. Selain itu, dalam mengatur pergerakan robot dapat dilakukan dengan cara manual seperti pada [9] dan bergerak secara otonom seperti pada [10].

d. Image Processing

Diperlukan kemampuan dalam hal pengolahan citra gambar sebagai sensor penglihatan pada robot.

e. Sensor dan Aktuasi

Diperlukan kemampuan dalam hal pengolahan dan pemfilter-an hasil pembacaan sensor sebelum diolah ke sub control system.

\section{Sistem Arsitektur Robot Mainland Surveillance}

Tahap pengembangan mailand surveillance robot ini dilakukan secara kontinuitas, dimulai dari perancangan elektronis dan mekanis yang didesain dan dibuat secara mandiri. Dalam perancangan sistem secara keseluruhan, mainland surveillance robot akan disusun dari komponen yang digambarkan pada Gambar 7. Sebuah kamera high definition system akan dipasang sebagai indera penglihat robot, dan sebagai core pengolahan gambar. Selain itu sensor jarak akan dipasang secara mengelilingi robot sebagai sensor bump pelindung robot dari halangan. Selain itu inertial measurement unit (IMU) sensor juga terpasang pada sistem robot ini. Pada tahap awal penelitian ini, penulis akan lebih fokus pada perancangan elektronis (Gambar 8) dan mekanis robot serta sistem gerak robot itu sendiri.

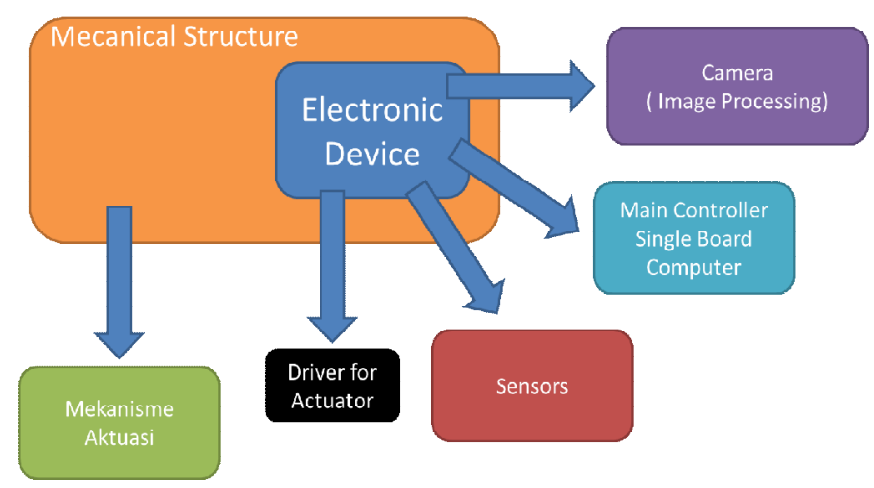

Gambar 7. Diagram sistem secara keseluruhan.

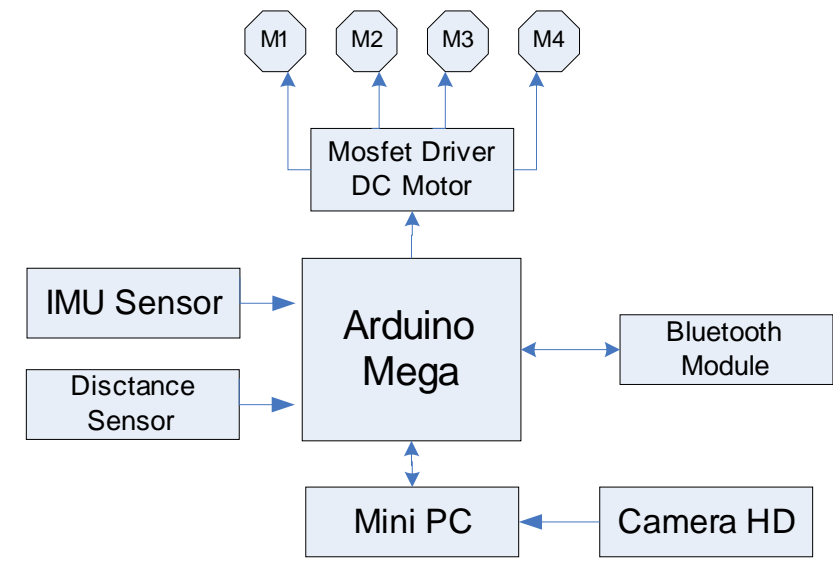

Gambar 8. Diagram sistem elektronis.

Pada penelitian ini, robot mailand surveillance menggunakan sensor IMU tipe 6050. Sensor ini memiliki konfigurasi sebagai berikut; memilik 6 derajat kebebasan, terdiri atas dua konfigurasi accelerometer dan gyroscope dengan komunikasi protokol data menggunakan I2C (inter ingrated circuit). Accelerometer digunakan untuk mengukur percepatan, mendeteksi dan mengukur getaran (vibrasi), dan mengukur percepatan akibat gravitasi. Sensor accelerometer mengukur percepatan akibat gerakan benda yang melekat padanya. Sedangkan gyroscope berfungsi untuk mengukur/menentukan orientiasi gerak yang berputar pada poros sumbu. Dari pengertian lain gyroscope berfungsi untuk menentukan gerakan sesuai dengan gravitasi yang dilakukan oleh pengguna. Dengan bantuan sensor IMU ini, arah pergerakan robot mailand surveillance memiliki error heading yang dapat dikoreksi. Teknik pengkoreksian arah heading dengan kendali logika fuzzy lebih jelas dipaparkan pada [11]. Selain itu, sensor jarak (distance) menggunakan ultrasonik sensor HC-04.

\section{E. Mainland Surveillance sebagai Militer Robot}

Tujuan akhir penelitian ini menciptakan sebuah robot militer pengintai dengan kemampuan gerak kesegala arah. Mekanisme gerak dan pengolahan citra gambar merupakan key success dari pengembangan robot ini. Tahap awal penelitian fokus pada penyelesaian inverse solution pada platform mecanum wheel. Selanjutnya penulis akan fokus pada penyelesaian pengolahan citra gambar sebagai sensor pemantau pada robot. Pengolahan citra gambar menggunakan OpenCV dengan computer based platform. Gambar 9 menjelaskan sistem arsitektur kendali gerak pada mainland surveillance. 


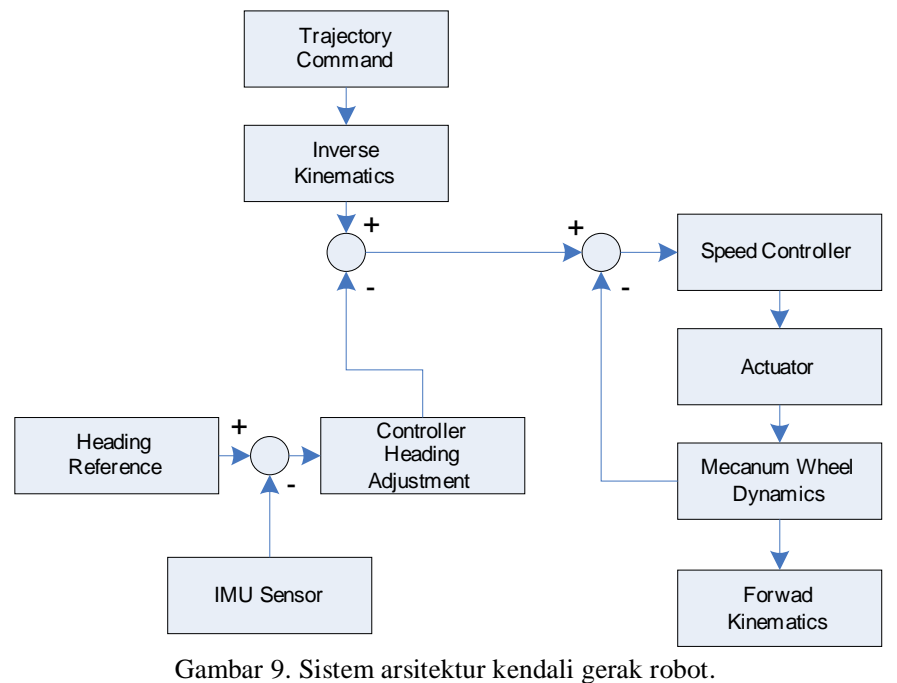

III. HASIL PENELITIAN

\section{A. Hasil Rancangan Robot Mainland Surveillance}

1) Perancangan Rangkaian Elektronis Robot

Diagram Blok desain elektronis robot yang dijelaskan pada Gambar 10 menggunakan Eagle Professional version 6.1, Eagle sebagai PCB desain mampu membuat rancangan PCB dengan multi layer atau berlapis - lapis. Pada penelitian ini pembuatan main controller PCB robot menggunakan layer sebanyak dua, yaitu top layer dan bottom layer. Berikut Gambar 10 hasil desain PCB pada penelitan ini, board PCB ini telah terintegrasi dengan sebuah Arduino Mega, artinya board PCB ini adalah sebagai shield yang juga telah memiliki 4 keluaran H-Bridge Mosfet Driver untuk menggerakan 4 buah motor pada robot mekanum ini.

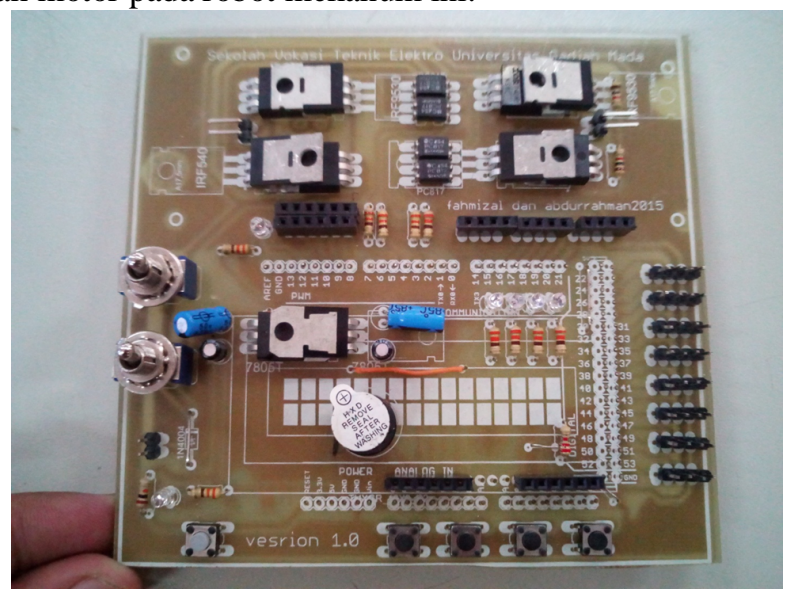

Gambar 10. Hasil rangkaian elektronis robot.

2) Perancangan mekanik Robot

Untuk tahap awal dari penelitian ini, penulis telah selesai medesain sistem mekanis (Gambar 11) yang akan diterapkan pada robot mainland surveillance. Robot ini dinamakan dengan nama VSR-UGM (Vocational Surveillance Robot Universitas Gadjah Mada).

Fahmizal: Sistem Gerak Robot Mainland Surveillance ...

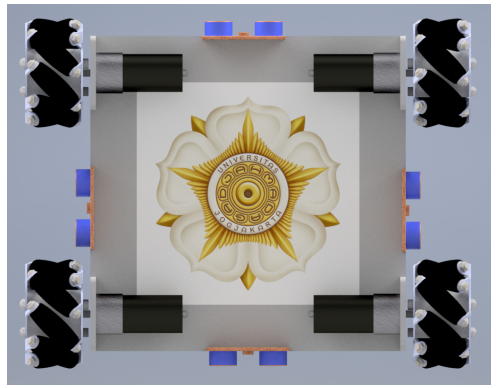

(a)

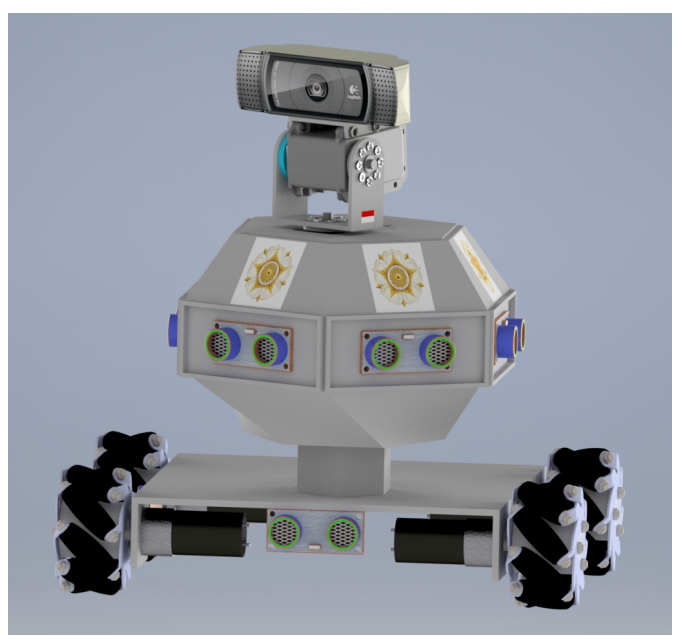

(b)

Gambar 11. (a) Rancangan CAD design VSR-UGM tampak bawah dan (b) CAD design VSR-UGM tampak keseluruhan.

Perancangan desain mekanis robot menggunakan Autodesk Inventor Professional version 2015, Inventor sebagai mekanikal desain mampu membuat rancangan robot yang akan digunakan sebagai prototype platform robot. Pada tahap ini penulis telah selesai mendesain dan melakukan proses manufaktur base bawah robot dengan bahan acrilic dengan ketebalan $5 \mathrm{~mm}$ seperti yang dijelaskan pada Gambar 12.

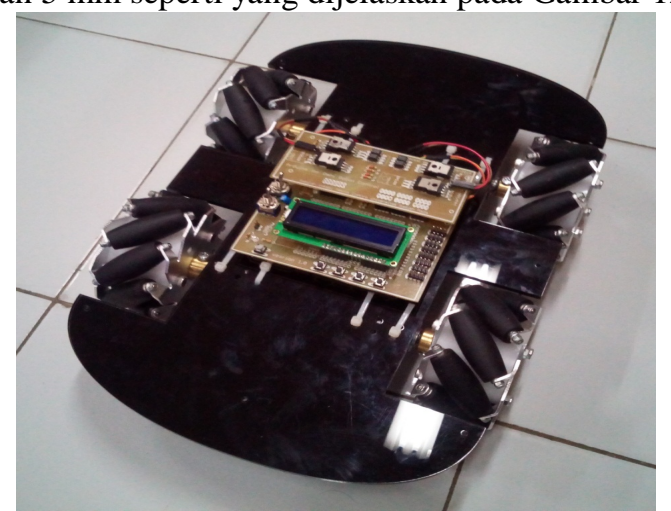

Gambar 12. Hasil manufaktur base bawah robot VSR-UGM.

\section{B. Kendali Motion Robot}

Robot ini dikendalikan dengan cara autonomous sistem dan manual sistem, pada sistem autonomous akan terpasang sensor IMU, sensor jarak ultrasonic SRF05 dan camera unit. Namun untuk tahap saat ini, kendali motion robot dilakukan dengan cara manual wirelese. Robot akan terkoneksi dengan sebuah perangkat Android-smartphones, dengan perangkat ini

$$
\text { p-ISSN:1693 - 2951; e-ISSN: 2503-2372 }
$$

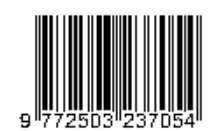


robot dapat dikendalikan keberbagai arah yang dijelaskan pada Gambar 13. Hasil dari sistem kendali dengan manual wirelese ini dapat dilihat pada [12].

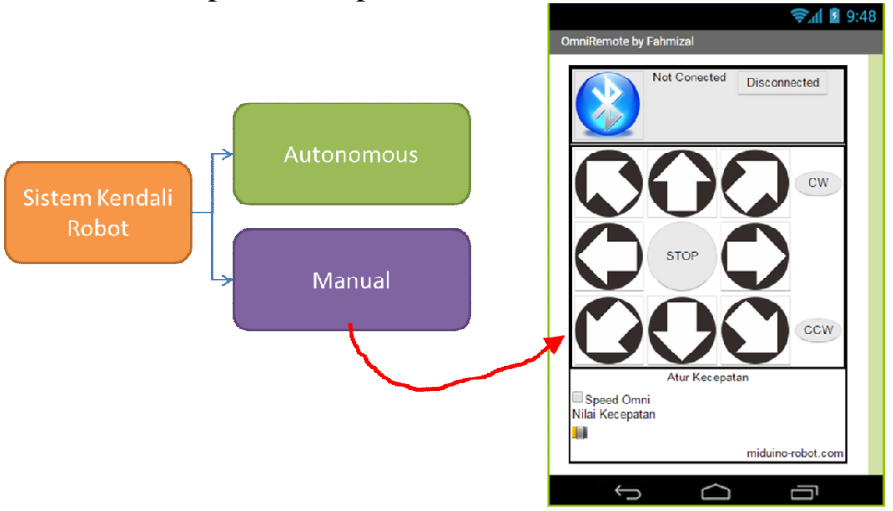

Gambar 13. Sistem kendali robot VSR-UGM

Dengan memberi perintah arah gerak yang berasal dari user, solusi inverse kinematic akan menghitung kecepatan dan arah putar dari masing-masing motor roda mecanum. Arah gerak pada mekanum platform menggunakan prinsip resultan gaya dimana arah vector kecepatan bergantung pada besar dan arah pada masing-masing motor. Saat arah putar M1 dan M3 (maju) dan M2 dan M3 (mundur) maka dapat di ilustrasikan vector gaya pergerakan robot seperti yang dijelaskan pada Gambar 14 dan Tabel 1.

TABEL I

ROTASI RODA UNTUK TRANSLATIONAL MOTION PADA MEKANUM PLATFORM

\begin{tabular}{|c|c|c|c|c|}
\hline Wheel Number & 1 & 2 & 3 & 4 \\
\hline \multicolumn{5}{|l|}{ Direction } \\
\hline \multirow{3}{*}{ North } & + & + & + & + \\
\hline & + & + & 0 & 0 \\
\hline & 0 & 0 & + & + \\
\hline \multirow{3}{*}{ South } & - & - & - & - \\
\hline & - & - & 0 & 0 \\
\hline & 0 & 0 & - & - \\
\hline \multirow{3}{*}{ East } & - & + & - & + \\
\hline & - & 0 & 0 & + \\
\hline & 0 & + & - & 0 \\
\hline \multirow{3}{*}{ West } & + & - & + & - \\
\hline & + & 0 & 0 & - \\
\hline & 0 & - & + & 0 \\
\hline North-East & 0 & + & 0 & + \\
\hline South-West & 0 & - & 0 & - \\
\hline North-West & + & 0 & + & 0 \\
\hline South-East & - & 0 & - & 0 \\
\hline
\end{tabular}

Untuk dapat bergerak kearah "North", indikasi “+" menyakatakan bahwa motor bergerak kearah maju dan "" bergerak kearah mundur, sedangkan "0" mengindentikasikan bawah motor dalam keadaan diam. Pada sistem pergerakan robot ini, arah sudut pergerakan robot dijelaskan pada Gambar 13.

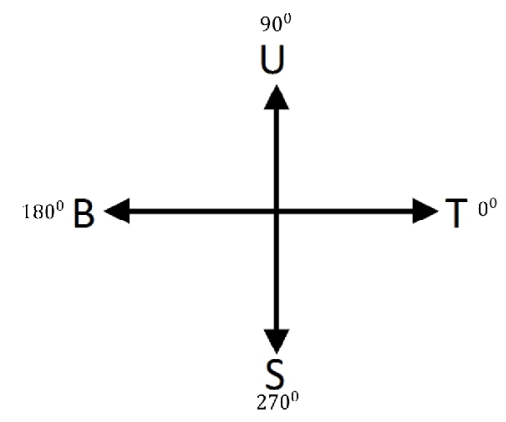

Gambar 13. Arah gerak pergerakan robot.

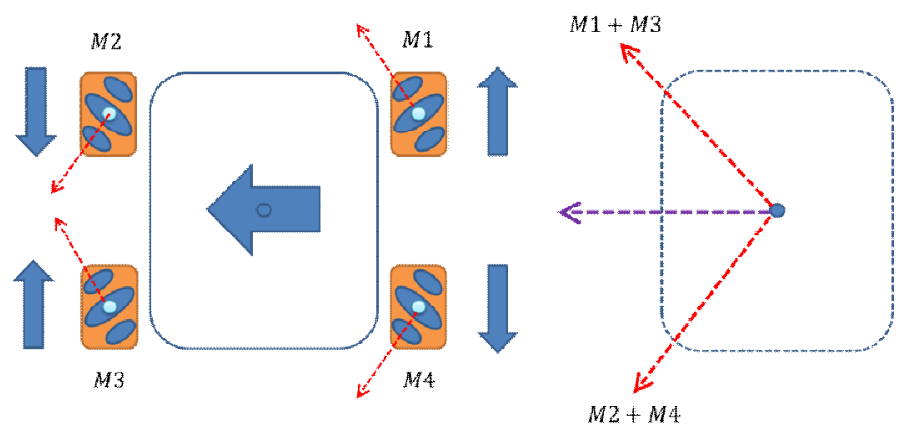

Gambar 14. Vektor gerak robot mecanum bergerak ke arah timur (180).

Gambar 15 dan 16 menjelaskan hasil rekamanan trajectory robot dengan menggunakan trajectory membentuk pola angka "8" dan tulisan "MRL" dari hasil penyelesain inverse solution pada robot. Untuk memudahkan pemantaun dari pengujian trajectory robot mecanum ini, maka dibuat dan dirancang pula sistem graphical user interface (GUI) nya dengan menggunakan Processing IDE seperti yang dijelaskan pada Gambar 17. Adapun trajectroy yang dapat diaplikasikan dan disimulasikan pada GUI ialah pergerakan circular, spherical dan elliptical. Dengan memformulakan suatu trajectory dengan vector kecepatan dari robot mecanum yang dapat dinotasikan dengan $\left[\begin{array}{llll}V_{1} & V_{2} & V_{3} & V_{4}\end{array}\right]^{T}$ dengan starting pose robot dinotasikan dengan $\left[\begin{array}{lll}x_{0} & y_{0} & \theta_{0}\end{array}\right]^{T}$ untuk dapat menuju pergerakan pada suatu trajectory dengan notasi $\left[\begin{array}{lll}x_{s p} & y_{s p} & \theta_{s p}\end{array}\right]^{T}$ maka formula dari trajectory circular, spherical dan elliptical dinyatakan dengan formula pada (8) (9) dan (10).

$$
\begin{aligned}
& {\left[\begin{array}{ll}
x_{s p} & y_{s p} \\
\theta_{s p}
\end{array}\right]^{T}=} \\
& {\left[10 \cos \omega_{r} t(\mathrm{~cm}) 10 \sin \omega_{r} t(\mathrm{~cm}) 0(\mathrm{rad})\right]^{T}} \\
& {\left[\begin{array}{c}
x_{s p} \\
y_{s p} \\
\theta_{s p}
\end{array}\right]=\left[\begin{array}{c}
e^{\omega_{r} t} \cos \omega_{r} t \\
e^{\omega_{r} t} \sin \omega_{r} t \\
0
\end{array}\right]} \\
& {\left[\begin{array}{lll}
x_{s p} & y_{s p} & \theta_{s p}
\end{array}\right]^{T}=} \\
& {\left[10 \cos \omega_{r} t(\mathrm{~cm}) 50 \sin \omega_{r} t(\mathrm{~cm}) 0(\mathrm{rad})\right]^{T}}
\end{aligned}
$$




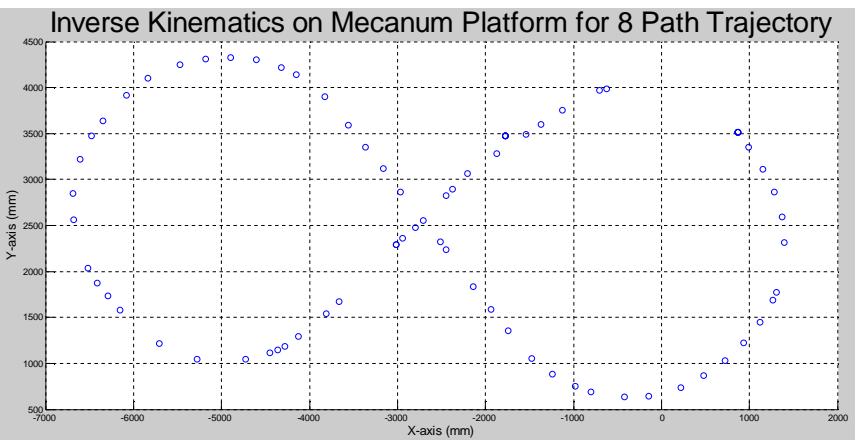

Gambar 15. Pola rekaman trajectory membentuk pola angka "8".

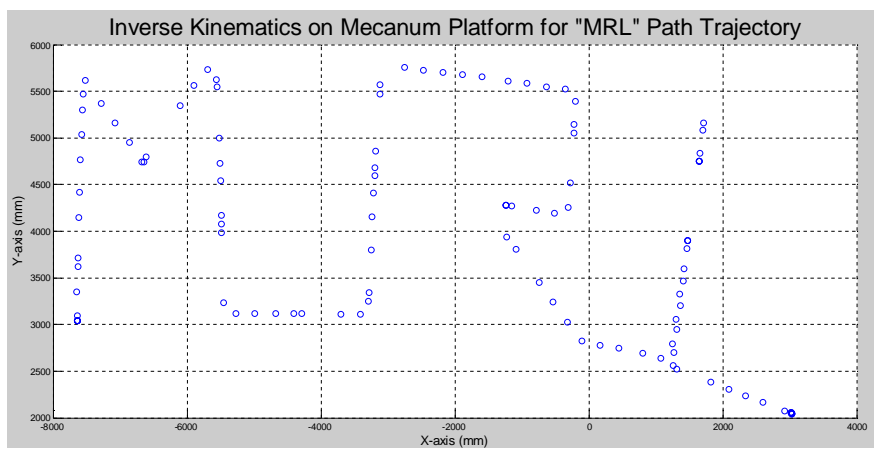

Gambar 16. Pola rekaman trajectory membentuk pola huruf "MRL".

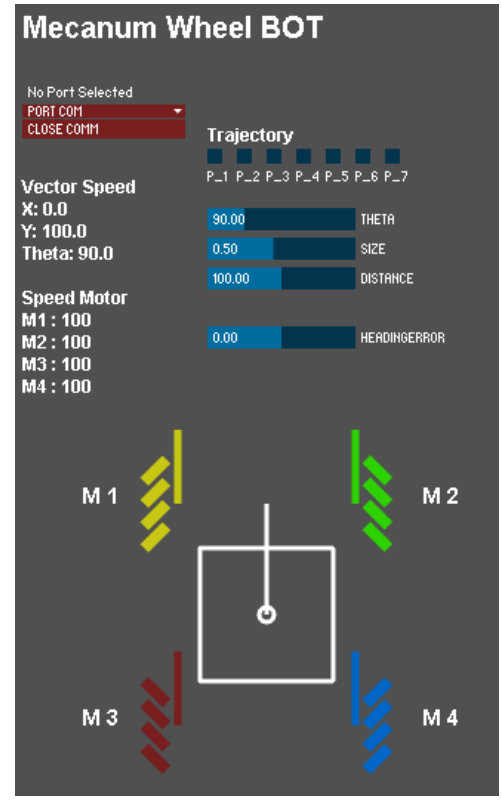

Gambar 17. GUI dalam mensimulasikan pergerakan trajectory mecanum wheel robot.

\section{KESIMPULAN}

Hasil penelitian ini dicapai sebuah pergerakan robot yang dapat bergerak kesegala arah dengan referensi arah timur sebagai arah sudut $0^{\circ}$, utara $\left(90^{\circ}\right)$, barat $\left(180^{\circ}\right)$ dan selatan $\left(270^{\circ}\right)$. Pemberian perintah arah robot menggunakan kendali manual wireless yang terinterasi dengan smartphones Android. Arah gerakan robot dengan menggunakan platform roda mecanum diperoleh dari kombinasi vector masing-masing motor roda. Dari hasil eksperiment diperoleh bahwa faktor terbesar yang mempengaruhi arah gerak heading robot ialah

Fahmizal: Sistem Gerak Robot Mainland Surveillance ... kondisi slip pada roda mecanum. Faktor ini dapat menyebabkan arah gerak heading robot menjadi tidak sesuai dengan yang di input-kan namun dapat dikoreksi dengan sebuah sensor IMU. Pada penelitian ini menitik beratkan pada penyelesaian invers kinematika dan penerapannya sebagai upaya merancang VSR-UGM sebagai prototype robot surveilance yang dapat bergerak kesegala arah dan memiliki pola trajectory yang dapat dirancang sesuai dengan keinginan dan diaplikasikan pada militer robot.

\section{UCAPAN TERIMAKASIH}

Penulis mengucapkan terima kasih kepada LPPM UGM pada skema hibah bersaing Penelitian Dosen Muda tahun 2015 atas dukungan yang diberikan.

\section{DAFTAR PUSTAKA}

[1] Al-Ammri, A. Salam, and Iman Ahmed. "Control of Omni-Directional Mobile Robot Motion." Al-Khwarizmi Engineering Journal 6, no. 4, 2010

[2] Airtrax, September 2006, Omni-Directional Technology: Changing the way vehicles move, [Online]. Available from: http://www.airtrax.com

[3] Br"aunl, T., Embedded Robotics: Mobile Robot Design and Applications with Embedded Systems, Springer, New York, 2003.

[4] Dickerson, Stephen L., and Brett D. Lapin. "Control of an omnidirectional robotic vehicle with Mecanum wheels." In Telesystems Conference, 1991. Proceedings. Vol. 1., NTC'91., National, pp. 323328. IEEE, 1991.

[5] Muir, P. F. \& C. P. Neuman, Kinematic Modeling for Feedback Control of an Omnidirection Wheeled Mobile Robot. In Robotics and Automation. Proceedings. 1987 IEEE International Conference on, vol. 4, pp. 1772-1778. IEEE, 1987.

[6] Wasson, Charles S. System engineering analysis, design, and development: Concepts, principles, and practices. John Wiley \& Sons, 2015.

[7] Dorf, Richard C., and Robert H. Bishop. Modern control systems. Pearson, 2011.

[8] Dewantoro, Gunawan; Susilo, Deddy; Adi, Prabata Pideksa. Implementasi Pengendali Logika Fuzzy pada Navigasi Robot Penjejak Dinding. Majalah Ilmiah Teknologi Elektro, [S.1.], v. 16, n. 2, p. 72-77, aug. 2017.

[9] Sedana, Pande Mastra; Indra Er, Ngurah; Linawati. Sistem Kendali Otomatis Prototype Robot Mobil untuk Parkir Pintar Menggunakan Komunikasi Nirkabel. Majalah Ilmiah Teknologi Elektro, [S.1.], v. 15, n. 2, p. 67-80, july 2016.

[10] Fahmizal, Chung-Hsien Kuo, "Development of a fuzzy logic wall following controller for steering mobile robots." In Fuzzy Theory and Its Applications (iFUZZY), 2013 International Conference on, pp. 7-12. IEEE, 2013.

[11] Fahmizal, Chung-Hsien Kuo, "Trajectory and heading tracking of a mecanum wheeled robot using fuzzy logic control." Instrumentation, Control and Automation (ICA), 2016 International Conference on. IEEE, 2016.

[12] Video implementation Mecanum Motion with Android Remote [Online]. Available on : http://youtu.be/bCFota5lyxg http://youtu.be/RSmo1JfEsXU 
[ Halaman ini sengaja dikosongkan] 